\title{
Influence of Marketing Mix on iPhone 6 Series Smartphone Purchase Decision
}

\author{
Pengaruh Bauran Pemasaran terhadap Keputusan Pembelian \\ Smartphone iPhone 6 Series
}

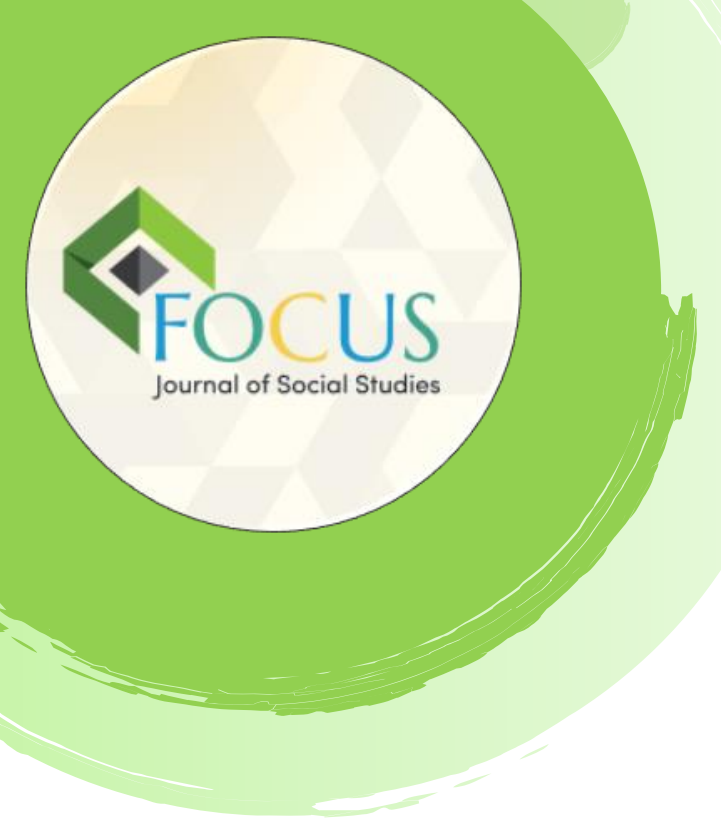

I Made Adnyana

Universitas Nasional

Jakarta, Indonesia

madeadnyana085@gmail.com

\section{Imelia Dinhar}

Universitas Nasional

Jakarta, Indonesia

imelia.manajemen@gmail.com

\section{DOI}

https://doi.org/10.37010/fcs.v2i1.284

\section{FOCUS}

Kata kunci: bauran pemasaran, produk, harga, tempat, promosi, keputusan pembelian

\section{Journal of Social Studies}

\section{Vol. 2 No. 1 \\ FEBRUARI \\ 2021}

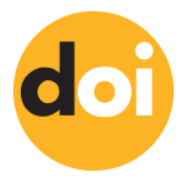

The purpose of this study was to analyze the effect of the marketing mix on purchasing decisions for the iPhone 6 Series smartphone. The research sample of 205 people was selected by the convenience sampling method. Data collection used questionnaires and multiple regression analysis was used as an analysis technique. The results of the study prove that products and promotions have a positive and significant effect on purchasing decisions. Meanwhile, price and place have no effect on purchasing decisions. The results of this study have implications for products, places, prices, and promotions that need to be improved in order to improve purchasing decisions.

Keywords: marketing mix, product, price, place, promotion, purchase decision

Abstrak

Tujuan penelitian ini adalah untuk menganalisis pengaruh bauran pemasaran terhadap keputusan pembelian smartphone iPhone 6 Series. Sampel penelitian sebanyak 205 orang dipilih dengan metode convenience sampling. Pengumpulan data menggunakan kuesioner dan analisis regresi berganda digunakan sebagai

teknik analisis. Hasil penelitian membuktikan bahwa produk dan promosi berpengaruh positif dan signifikan terhadap keputusan pembelian. Sedangkan harga dan tempat tidak berpengaruh terhadap keputusan pembelian. Hasil penelitian ini berimplikasi terhadap produk, tempat, harga, dan promosi yang perlu ditingkatkan guna meningkatkan keputusan pembelian. 


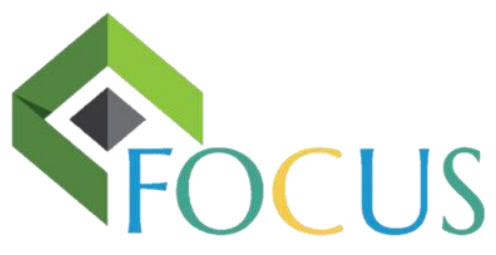

\section{PENDAHULUAN}

Perkembangan teknologi, informasi dan komunikasi sedang berkembang dengan cepat membuat setiap individu terdorong untuk memiliki alat mampu memenuhi kebutuhan mengakses kemajuan teknologi, informasi, dan komunikasi, salah satunya dengan menggunakan ponsel. Sekarang telah sampai kepada Revolusi Industri 4.0 ciri utamanya terjadi disrupsi di berbagai lini yang semuanya telah masuk pada era digitalisasi secara penuh dan dinamis (uncertainty) (Sefudin \& Darwin, 2020). Ponsel pada awal kemunculannya adalah alat yang diciptakan untuk mengakomodasi kebutuhan komunikasi manusia yang digunakan dengan cara bergerak di sekitar. Konsep ini dimaksudkan untuk menggantikan konsep telepon jaringan konvensional yang menggunakan kabel sebagai perantara yang dirasakan dibatasi oleh ruang terbatas.

Di antara banyak beredarnya smartphone di Indonesia, iPhone merupakan salah satu smartphone yang masih memiliki minat pembeli yang banyak. iPhone merupakan salah satu produk smartphone yang diproduksi oleh perusahaan terkemuka di dunia yaitu Apple.Inc. Apple baru-baru ini melaporkan hasil pendapatan kuartal keempat 2019 mereka. Mereka dikabarkan telah menghasilkan keuntungan sebesar USD64 miliar, atau sekitar Rp900 triliun dalam tiga bulan terakhir. Pendapatan tersebut dikabarkan meningkat sebesar USD1 miliar atau Rp14 triliun dalam setahun ini. Selain itu, penghasilan per saham mereka mencapai USD3,3 atau Rp46 ribu, sementara arus kas operasi mereka mencapai USD19,9 miliar atau Rp279 triliun (Laksana, 2019)

Dalam suatu analis mengharapkan Apple untuk mendapatkan pendapatan di angka USD62,9 miliar atau sekira Rp884 triliun. Mereka juga mengharapkan perusahaan asal Cupertino tersebut akan memiliki keuntungan USD2,84 atau Rp40 ribu per saham. Sedangkan untuk penghasilan bersih Apple untuk kuartal ini adalah USD13 miliar atau Rp182 triliun, turun dari USD14 miliar atau Rp196 triliun yang diposting Apple pada kuartal keempat 2018. Namun, peningkatan sekuensial juga mencakup pendapatan dari jajaran iPhone 2019, sehingga kekhawatiran sesungguhnya sekali lagi adalah penurunan laba bersih (Laksana, 2019).

Beralih ke penjualan iPhone, pada tahun ini dikabarkan bahwa penjualan produk tersebut kembali melemah. Pada kuartal ini, penjualan iPhone hanya dapat menghasilkan USD33 miliar atau Rp464 triliun, menurun USD3 miliar atau Rp42 triliun dari tahun lalu. Penjualan di Tiongkok juga tidak terlalu baik pada kuartal ini. Apple kehilangan sekitar USD300 juta atau Rp42 miliar. Apple juga dikabarkan mendapati penurunan pendapatan ke angka 24 persen di Tiongkok dari kuartal pertama 2019, di mana penurunannya mencapai 2 persen (Laksana, 2019).

Walaupun penjualan terlihat melemah, namun iPhone masih diminat masyarakat di Indonesia. Per periode Mei 2019, iPhone mencatatkan angka 5,52 persen saja, naik sedikit dari periode Mei 2018 yang memiliki marketshare 3,77 persen. Hal ini dipengaruhi oleh berbagai faktor, seperti harganya yang tergolong mahal, kapasitas baterai yang lebih kecil dan tidak memiliki slot memori eksternal. Walau begitu, iPhone punya keunggulan yang tak dimiliki oleh ponsel lain, seperti performa dan kamera yang lebih baik, privasi lebih aman dan update software lebih cepat. Beberapa seri iPhone yang tergolong paling laris terjual adalah iPhone XR, iPhone XS, iPhone XS MAX dan iPhone 8 Plus. iPhone merupakan produk dari Apple, perusahaan teknologi multinasional yang bermarkas di Cupertino, California (Zakiah, 2020).

Salah satu iPhone series yang masih memiliki minat beli konsumen yang cukup tinggi. Smartphone yang diproduksi oleh Apple, iPhone 6s dan iPhone 6s Plus ini membawa perubahan yang cukup signifikan, seperti penggunaan chipset A9, kamera yang di-updgrade menjadi 12 megapiksel, fitur 3D Force Touch, dan iOS 9. Angka penjualan 13 juta unit dalam 3 hari memecahkan rekor histori penjualan dari perangkat Apple sebelumnya, Apple iPhone 6 dan iPhone 6 Plus, yang menyentuh angka 10 juta penjualan pada minggu pertamanya setelah dirilis. Kunci suksesnya angka penjualan ini tidak hanya karena fitur yang disajikan saja, namun juga strategi marketing dari Apple sendiri terbilang pintar. Selain di Amerika Serikat, penjualan pertama Apple iPhone 6s dan iPhone 6s Plus ini juga diadakan di Tiongkok. Kabarnya, iPhone 6s dan iPhone 6s Plus ini akan menyambangi di berbagai belahan dunia pada akhir tahun 2015 (beritatekonologi.com, 2015). Sehingga dalam hal ini bauran pemasaran sangat diperlukan untuk menarik minat pembeli.

Berdasarkan penelitian yang dilakukan oleh Saputra dan Suprihadi (2013) bahwa bauran pemasaran yang terdiri atas produk, harga, tempat, dan promosi dapat mempengaruhi keputusan pembelian konsumen. 
Bauran pemasaran adalah seperangkat variabel pemasaran yang dapat dikendalikan dan dipadukan oleh perusahaan untuk menghasilkan tanggapan yang diinginkan di dalam pasar sasaran (Saputra \& Suprihadi, 2013). Menurut analisis bauran pemasaran, ini adalah tentang cara membuat, berkomunikasi dan memberikan nilai kepada konsumen untuk keuntungan market. Bauran pemasaran adalah sekumpulan alat pemasaran (Marketing Mix) yang dapat digunakan oleh perusahaan untuk mencapai tujuan pemasarannya dalam pasar sasaran, yang terdiri dari produk (product), harga (price), distribusi (place), dan promosi (promotion) (Kotler, 2009). Bauran pemasaran adalah Salah satu unsur dalam strategi pemasaran terpadu adalah strategi bauran pemasaran yang merupakan strategi yang dijalankan perusahaan, yang berkaitan dengan penentuan bagaimana perusahaan menyajikan penawaran produk pada segmen pasar tertentu, yang merupakan sasaran pasarnya. Bauran pemasaran rangkaian sarana pemasaran taktis terpadu yang dapat dikendalikan (produk, harga, tempat, dan promosi) untuk mengetahui respons pasar sasaran yang diinginkan oleh perusahaan (Ulus, 2013).

Dalam konteks ini, menciptakan berkaitan dengan manajemen produk, yang sangat penting untuk setiap profit dan non-profit organisasi, mulai dari ide (dalam hal keinginan konsumen, kebutuhan dan tuntutan) hingga produk akhir atau jasa. Perilaku konsumen merupakan proses pengambilan keputusan yang dipengaruhi oleh beberapa faktor, termasuk aktivitas fisik dalam usaha mencari informasi mengenai suatu produk dan jasa, untuk melakukan evaluasi, menerima membeli dan menggunakan suatu produk yang ditawarkan (Hermawan, 2015). Perilaku konsumen diwujudkan dengan membeli produk dan jasa untuk kebutuhan memuaskan. Tindakan pembelian adalah proses yang kompleks didahului dengan tindakan seleksi, yang memiliki pedoman kriteria ekonomi, dijamin dengan unsur-unsur psikologis, karena keuangan pelanggan dibandingkan dengan harga sebuah produk atau jasa (Makarewicz, 2013).

Produk merupakan elemen yang sangat penting bagi konsumen untuk melakukan pembelian terhadap suatu barang. Secara konseptual produk adalah pemahaman subyektif dari produsen atas sesuatu yang bisa ditawarkan sebagai usaha untuk mencapai tujuan organisasi melalui pemenuhan kebutuhan dan keinginan konsumen, sesuai dengan kompetensi dan kapasitas organisasi serta daya beli (Supriyono, Hasiolan, \& Warso, 2014). Produk adalah segala sesuatu yang dapat ditawarkan ke pasar untuk diamati, disukai, dan dibeli untuk memuaskan sesuatu kebutuhan atau keinginan. Oleh karena produk dapat memenuhi kebutuhan tertentu maka produk dapat juga diartikan sebagai sekelompok nilai yang memberikan kepuasan pada pemakainya (Zulaicha \& Irawati, 2016).

Harga adalah sejumlah uang sebagai alat tukar untuk produk memperoleh atau jasa. Banyak perusahaan yang kurang memperhatikan faktor ini dengan menetapkan harga yang terlalu tinggi sehingga perusahaan tidak dapat bertahan dalam waktu yang panjang atau keluar dari bisnis karena tidak mematok harga sesuai pasar. Harga ditetapkan menjadi sesuai dengan ekonomi konsumen, sehingga mereka dapat membeli barang-barang (Foster, 2016). Lokasi atau tempat sering menentukan keberhasilan perusahaan, karena lokasi itu terkait era dengan pasar potensial perusahaan. Selain itu, lokasi juga mempengaruhi dimensi strategi seperti fleksibilitas, persaingan, penentuan posisi, dan fokus. Fleksibilitas lokasi adalah ukuran sejauh mana perusahaan dapat bereaksi terhadap perubahan dalam situasi ekonomi. Keputusan pemilihan lokasi berkaitan dengan komitmen jangka panjang untuk aspek-aspek yang padat modal, maka perusahaan benar-benar perlu mempertimbangkan dan memilih lokasi yang responsif terhadap situasi ekonomi, demografi, budaya dan persaingan di masa depan (Selang, 2013).

Promosi merupakan tombak dari semua alat dalam bauran pemasaran yang berperan utama adalah komunikasi persuasif. Promosi meliputi, iklan, personal selling, promosi penjualan dan menjual alat-alat lainnya. Promosi adalah salah satu elemen pasar campuran, dan istilah yang digunakan sering dalam pemasaran. Campuran promosi atau alat promosi yang personal selling, periklanan, promosi penjualan, pemasaran langsung, dan publisitas (Odunlami \& Emmanuel, 2014). Keputusan pembelian yang dilakukan oleh konsumen didasarkan pada berbagai motif dan dorongan tertentu. Semakin kuat dorongan konsumen dan motif, semakin kuat keputusan untuk membeli produk tertentu (Amron, 2018).

Penelitian ini akan dilakukan pada mahasiswa pengguna iPhone 6 Series di Universitas Nasional Jakarta. Hal tersebut didasarkan pada pengamatan yang dilakukan oleh peneliti bahwa minat beli mahasiswa pada iPhone 6 Series masih cukup tinggi karena saat ini harganya sudah turun akibat adanya iPhone series terbaru. Pemasaran 


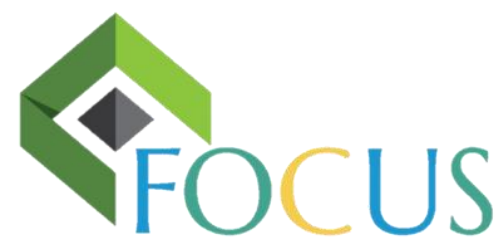

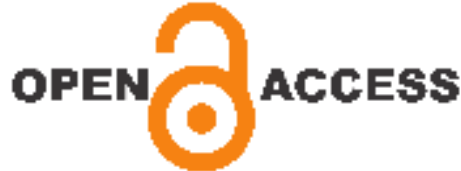

yang dilakukan oleh pihak iPhone sendiri sangat menarik minat perhatian mahasiswa untuk melakukan pembelian pada iPhone 6 series ini. Maka berdasarkan pada penjelasan dan permasalahan yang ada tersebut peneliti tertarik untuk melakukan penelitian tentang Pengaruh Bauran Pemasaran terhadap Keputusan Pembelian Smartphone Apple iPhone 6 Series pada Mahasiswa Universitas Nasional Jakarta.

\section{METODE}

Penelitian ini menggunakan jenis penelitian kuantitatif, yaitu penelitian yang menyajikan tahap lebih lanjut dari observasi. Pemilihan pendekatan kuantitatif dalam penelitian ini karena data yang didapat dari instrumen penelitian akan diolah dengan menggunakan analisis statistik, sehingga penyajian data berupa angkaangka. Penelitian ini akan dilakukan di Universitas Nasional Jakarta yang beralamat di Jl. Sawo Manila, RT.14/RW.3, Ps. Minggu, Kec. Ps. Minggu, Kota Jakarta Selatan, Daerah Khusus Ibukota Jakarta. Periode penelitian ini yaitu dilakukan pada periode bulan Agustus-November 2020. Populasi yang digunakan dalam penelitian ini adalah pengguna iPhone 6 Series di Universitas Nasional Jakarta. Teknik sampling yang digunakan adalah convenience sampling. Jenis dan sumber data yang digunakan dalam penelitian ini adalah data primer merupakan data yang diperoleh secara langsung dari pihak pertama. Teknik pengumpulan data yang digunakan dalam penelitian ini adalah dengan menggunakan kuesioner. Skala yang digunakan untuk memberikan skoring angket dalam penelitian ini adalah skala Likert. Analisis yang digunakan dalam penelitian ini adalah regresi linier berganda (multiple regression analysis) menggunakan software SPSS.

\section{HASIL DAN PEMBAHASAN}

\section{Hasil}

\section{Data Responden}

Hasil penelitian menunjukkan latar belakang responden berdasarkan jenis kelamin yang beragam. Mayoritas responden adalah berjenis kelamin perempuan dengan persentase 63,4\% (130 orang), sedangkan responden yang berjenis kelamin laki-laki memiliki persentase sebesar 36,6\% (75 orang). Hasil penelitian menunjukkan latar belakang responden berdasarkan usia yang beragam. Mayoritas responden adalah berusia < 18-25 tahun dengan persentase 53,7\% (110 orang), responden yang berusia 26-30 tahun sebanyak 30,7\% (63 orang), responden dengan usia 31-35 tahun sebesar 9,3\% (19 orang), responden dengan usia 36-40 tahun sebanyak 4,9\% (10 orang), sementara responden yang berusia > 40 tahun sebanyak 1,5\% (3 orang). Hasil penelitian menunjukkan latar belakang responden berdasarkan lama penggunaan iPhone 6 Series yang beragam. Mayoritas responden telah menggunakan iphone 6 Series selama $<1$ tahun yaitu sebesar 62,9\% (129 orang). Sementara responden yang menggunakan iPhone 6 Series $>1$ tahun sebesar 37,1\% (76 orang).

\section{Data Deskripsi Hasil Kuesioner}

Berdasarkan hasil analisis didapatkan variabel produk (X1) memiliki mean total sebesar 4,30 yang mendekati skor 5, artinya produk iPhone 6 Series memiliki citra merek yang sangat baik di hati konsumen. Hal ini bisa dilihat dari distribusi jawaban responden yang paling banyak adalah sangat setuju. Indikator X1.5 dengan pernyataan "Saya tertarik membeli iPhone karena memiliki desain yang menarik" merupakan indikator yang memiliki nilai mean tertinggi sebesar 4,52. Dengan demikian produk iPhone 6 Series memiliki desain yang menarik sehingga konsumen tertarik untuk membeli iPhone 6 Series. 
Variabel harga (X2) memiliki mean total sebesar 4,26 yang mendekati skor 5, artinya produk iPhone 6 Series memiliki taraf harga yang sangat baik di kalangan penggunanya. Hal ini bisa dilihat dari distribusi jawaban responden yang paling banyak adalah setuju. Indikator X2.2 dengan pernyataan "Saya membeli iPhone karena harganya sesuai dengan kemasannya" merupakan indikator yang memiliki nilai mean tertinggi sebesar 4,35. Dengan demikian produk iPhone 6 Series memiliki kemasan yang baik sehingga ini mempengaruhi harga produk iPhone 6 Series. Variabel tempat (X3) memiliki mean total sebesar 3,93 yang mendekati skor 4, artinya produk iPhone 6 Series memiliki lokasi penjualan yang strategis dan dinamis sehingga mudah dijangkau oleh konsumen. Hal ini bisa dilihat dari distribusi jawaban responden yang paling banyak adalah setuju. Indikator X3.2 dengan pernyataan "Saya membeli iPhone Karena lokasi penjualannya mudah diakses" merupakan indikator yang memiliki nilai mean tertinggi sebesar 4,07. Dengan demikian produk iPhone 6 Series memiliki lokasi penjualan yang mudah diakses sehingga konsumen membeli produk tersebut.

Selanjutnya berdasarkan hasil analisis variabel promosi (X4) memiliki mean total sebesar 3,91 yang mendekati skor 4, artinya produk iPhone 6 Series memiliki strategi promosi yang baik sehingga menjadikan konsumen membeli produk iPhone. Hal ini bisa dilihat dari distribusi jawaban responden yang paling banyak adalah setuju. Indikator X4.7 dengan pernyataan "Saya membeli iPhone setelah melihat produknya di internet" merupakan indikator yang memiliki nilai mean tertinggi sebesar 4,00. Dengan demikian promosi yang dilakukan oleh iPhone 6 Series adalah melalui internet sehingga konsumen menjadi tahu dan membeli produk tersebut.

Keputusan pembelian (Y) memiliki mean total sebesar 4,25 yang mendekati skor 5, artinya produk iPhone 6 Series memiliki konsumen yang mampu memutuskan pembelian yang baik sehingga menjadikan konsumen membeli produk iPhone. Hal ini bisa dilihat dari distribusi jawaban responden yang paling banyak adalah setuju. Indikator Y3 dengan pernyataan "Saya membeli iPhone karena mendapatkan informasi dari keluarga dan saudara" dan indikator Y7 dengan pernyataan "Keputusan saya membeli iPhone adalah tepat" merupakan indikator yang memiliki nilai mean tertinggi masing-masing sebesar 4,44. Dengan demikian pembelian iPhone 6 Series dikarenakan adanya informasi dari saudara dan keluarga, selain itu konsumen merasa sudah tepat melakukan pembelian iPhone 6 Series.

Uji Validitas Produk $(P)$

Tabel 1. Uji Validitas Produk (X1)

\begin{tabular}{lcc}
\hline \multicolumn{1}{c}{ Item Kuesioner } & Pearson Product Moment (r) & Signifikansi \\
\hline Saya pernah mendengar merek iPhone sebelumnya & 0,525 & 0,000 \\
Saya dapat mengenali istilah iPhone & 0,702 & 0,000 \\
Saya dapat mengenali simbol dan logo iPhone & 0,615 & 0,000 \\
Saya tertarik membeli iPhone karena memiliki kemasan yang menarik & 0,568 & 0,000 \\
Saya tertarik membeli iPhone karena memiliki desain yang menarik & 0,632 & 0,000 \\
Saya tertarik membeli iPhone karena memiliki bentuk yang unik & 0,602 & 0,000 \\
Saya membeli iPhone karena memiliki fungsi yang bagus & 0,562 & 0,000 \\
Saya membeli iPhone karena daya yang tahan lama & 0,740 & 0,000 \\
Saya membeli iPhone karena memiliki kemudahan dalam pengoperasiannya & 0,605 & 0,000 \\
Saya membeli iPhone karena memiliki fitur aplikasi yang menarik & 0,514 & 0,000 \\
Saya membeli iPhone karena memiliki daya jelajah internet yang baik & 0,501 & 0,000 \\
\hline Sumber: Diolah 2020 rat & &
\end{tabular}

Sumber: Diolah (2020)

Sesuai dengan sajian data di atas menunjukkan keseluruhan item yang terdapat pada variabel produk memiliki nilai $\mathrm{r}$ dengan tingkat signifikan kurang dari 5\% (0,05), sehingga dapat dinyatakan seluruh item di variabel produk valid. 
Tabel 2. Uji Validitas Harga (X2)

\begin{tabular}{lcc}
\hline \multicolumn{1}{c}{ Item Kuesioner } & Pearson Product Moment (r) & Signifikansi \\
\hline Saya membeli iPhone karena harganya sesuai dengan manfaatnya & 0,610 & 0,000 \\
Saya membeli iPhone karena harganya sesuai dengan kemasannya & 0,748 & 0,000 \\
Saya membeli iPhone karena harganya terjangkau & 0,648 & 0,000 \\
Saya membeli iPhone karena terdapat potongan harga & 0,563 & 0,000 \\
Saya membeli iPhone karena terdapat potongan harga pada waktu/periode tertentu & 0,610 & 0,000 \\
\hline Sumber: Diolah (2020) &
\end{tabular}

Sesuai dengan sajian data di atas menunjukkan keseluruhan item yang terdapat pada variabel harga memiliki nilai $\mathrm{r}$ dengan tingkat signifikan kurang dari 5\% (0,05), sehingga dapat dinyatakan seluruh item di variabel harga valid.

\section{Tabel 3. Uji Validitas Tempat (X3)}

\begin{tabular}{lcc}
\hline \multicolumn{1}{c}{ Item Kuesioner } & Pearson Product Moment (r) & Signifikansi \\
\hline Saya membeli iPhone karena lokasi penjualannya dapat dijangkau & 0,601 & 0,000 \\
Saya membeli iPhone Karena lokasi penjualannya mudah diakses & 0,734 & 0,000 \\
Saya membeli iPhone karena lokasi penjualannya dapat ditemui dengan mudah & 0,602 & 0,000 \\
Saya membeli iPhone karena lokasi reparasinya dapat ditemukan dengan mudah & 0,656 & 0,000 \\
Saya membeli iPhone karena kenyamanan lokasi penjualannya & 0,656 & 0,000 \\
\hline
\end{tabular}

Sumber: Diolah (2020)

Sesuai dengan sajian data di atas menunjukkan keseluruhan item yang terdapat pada variabel tempat memiliki nilai $\mathrm{r}$ dengan tingkat signifikan kurang dari 5\% (0,05), sehingga dapat dinyatakan seluruh item di variabel tempat valid.

\section{Tabel 4. Uji Validitas Promosi (X4)}

\begin{tabular}{|c|c|c|}
\hline Item Kuesioner & Pearson Product Moment (r) & Signifikansi \\
\hline $\begin{array}{l}\text { Saya membeli iPhone karena melihat iklannya di media cetak seperti majalah, koran dan } \\
\text { tabloid }\end{array}$ & 0,546 & 0,000 \\
\hline $\begin{array}{l}\text { Saya membeli iPhone karena pihak penjual memaparkan segala informasi tentang } \\
\text { produk }\end{array}$ & 0,673 & 0,000 \\
\hline Saya membeli iPhone karena rayuan dari penjual & 0,691 & 0,000 \\
\hline Saya membeli iPhone karena penjual mencontohkan pengoperasian produknya & 0,631 & 0,000 \\
\hline Saya membeli iPhone karena penjual memeragakan keunggulan produknya & 0,676 & 0,000 \\
\hline Saya membeli iPhone setelah membaca dan melihat katalog yang diberikan & 0,639 & 0,000 \\
\hline Saya membeli iPhone setelah melihat produknya di internet & 0,709 & 0,000 \\
\hline Saya membeli iPhone karena mendengarkan produknya dari rekan atau keluarga & 0,521 & 0,000 \\
\hline
\end{tabular}

Sumber: Diolah (2020)

Sesuai dengan sajian data di atas menunjukkan keseluruhan item yang terdapat pada variabel promosi memiliki nilai $\mathrm{r}$ dengan tingkat signifikan kurang dari 5\% (0,05), sehingga dapat dinyatakan seluruh item di variabel promosi valid.

\section{Tabel 5 Uji Validitas Keputusan Pembelian (Y)}

\begin{tabular}{lcc}
\hline \multicolumn{1}{c}{ Item Kuesioner } & Pearson Product Moment (r) & Signifikansi \\
\hline Saya membeli iPhone agar dapat memenuhi kebutuhan saya & 0,525 & 0,000 \\
Saya membeli iPhone karena pengaruh dari lingkungan sekitar & 0,502 & 0,000 \\
Saya membeli iPhone karena mendapatkan informasi dari keluarga dan saudara & 0,743 & 0,000 \\
Saya membeli iPhone karena mendapatkan informasi dari teman & 0,748 & 0,000 \\
Saya mengetahui merek-merek smartphone yang diminati & 0,771 & 0,000 \\
\hline
\end{tabular}


Saya membandingkan merek lain dengan iPhone sebelum membeli

Keputusan saya membeli iPhone adalah tepat

0,749

0,744

0,751

Tidak ada penyesalan dalam diri saya setelah membeli iPhone

Saya merasa puas setelah membeli iPhone

0,549

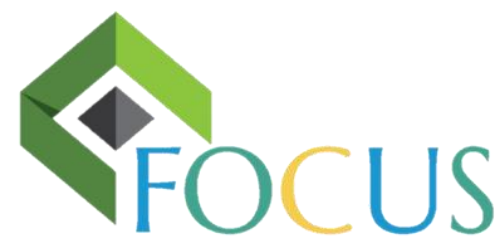

Sumber: Diolah (2020)

Sesuai dengan sajian data di atas menunjukkan keseluruhan item yang terdapat pada variabel keputusan pembelian memiliki nilai $\mathrm{r}$ dengan tingkat signifikan kurang dari 5\% $(0,05)$, sehingga dapat dinyatakan seluruh item di variabel keputusan pembelian valid.

\section{Uji Reliabilitas}

Uji reliabilitas akan dilakukan dengan menggunakan uji statistik cronbach's alpha (a) dengan ketentuan bahwa variabel yang diteliti dinyatakan reliabel apabila nilai cronbach's alpha (a) adalah di atas 0,6 . Berikut ini adalah hasil uji reliabilitas dari penelitian ini:

\section{Tabel 6. Hasil Uji Reliabilitas Variabel Penelitian}

\begin{tabular}{lc}
\hline \multicolumn{1}{c}{ Variabel Penelitian } & Cronbach's Alpha \\
\hline Produk (X1) & 0,817 \\
Harga (X2) & 0,631 \\
Tempat (X3) & 0,659 \\
Promosi (X4) & 0,789 \\
Keputusan Pembelian (Y) & 0,831 \\
\hline mber: Diolah (2020)
\end{tabular}

Berdasarkan hasil pengujian reliabilitas yang telah disajikan pada tabel, diketahui bahwa masing-masing dari Variabel yang diteliti-dalam penelitian ini memiliki nilai cronbach's alpha yang lebih dari 0,6. Hasil pengujian ini menjelaskan bahwa instrumen dari setiap variabel yang dianalisis dalam penelitian ini telah konsisten dan dapat digunakan untuk menjelaskan setiap variabel.

Uji Asumsi Klasik

Tabel 7. Hasil Uji Normalitas

\begin{tabular}{ll}
\hline & Unstandardized Residual \\
\hline $\mathrm{N}$ & 205 \\
Kolmogorov Smirnov & 1,089 \\
Asymp. Sig & 0,186 \\
Sumber: Diolah (2020) &
\end{tabular}

Hasil uji normalitas menunjukkan nilai Kolmogorov Smirnov 1,089 dengan signifikan 0,186, dimana nilai tersebut adalah lebih besar dari 0,05. Sehingga dapat disimpulkan bahwa data terdistribusi normal.

Tabel 8. Hasil Uji Multikolinieritas

\begin{tabular}{lcc}
\hline \multicolumn{1}{c}{ Variabel Bebas } & VIF & Tolerance \\
\hline Produk (X1) & 3,083 & 0,324 \\
Harga (X2) & 3,101 & 0,323 \\
Tempat (X3) & 1,271 & 0,787 \\
Promosi (X4) & 1,341 & 0,746 \\
\hline
\end{tabular}




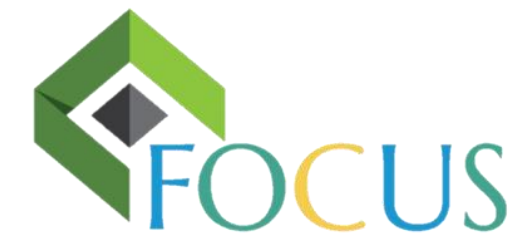

\section{oren Aacecess}

Berdasarkan tabel di atas, nilai tolerance X1 sebesar 0,324, X2 sebesar 0,323, X3 sebesar 0,787, dan X4 sebesar 0,746. Jika dilihat dari nilai tolerance, maka terbebas dari multikolinieritas. Sedangkan nilai VIF X1 sebesar 3,083, X2 sebesar 3,101, X3 sebesar 1,271 dan X4 sebesar 1,341. Berdasarkan hasil uji multikolinearitas menunjukkan nilai tolerance $\geq 0,10$ atau VIF $\leq 10$. Artinya nilai VIF setiap varibel $<10$, maka data tersebut terbebas dari multikolinieritas.

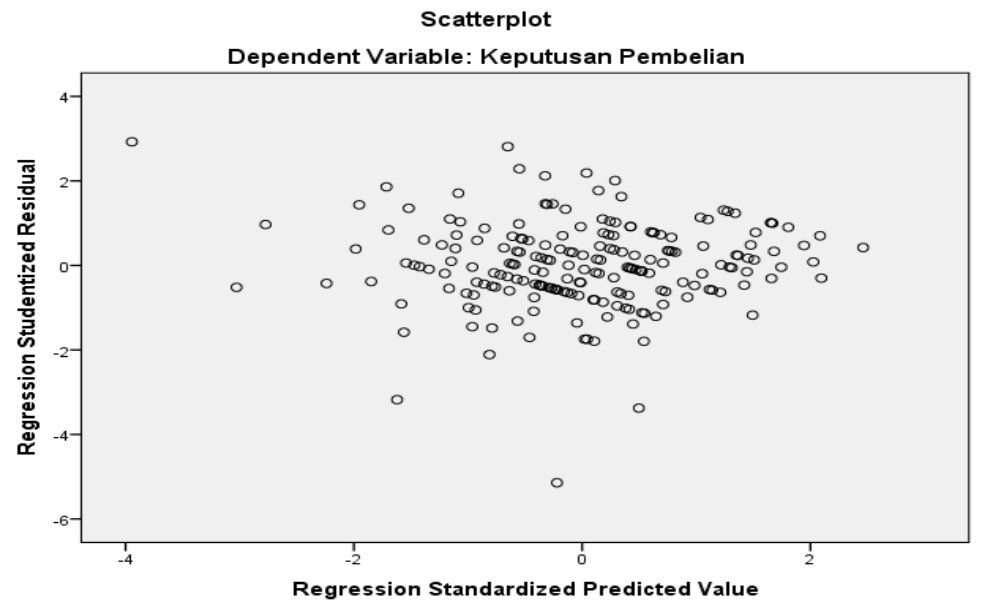

Gambar 1. Hasil Uji Heterokedastisitas

Suatu regresi dikatakan heterokedastisitas apabila diagram pancar residual membentuk pola tertentu. Regresi dikatakan terbebas dari heterokedastisitas dan memenuhi persyaratan asumsi klasik jika diagram pancar residual tidak membentuk suatu pola tertentu. Berdasarkan gambar di atas, maka dsisimpulkan bahwa data terbebas dari heterokedastisitas.

Tabel 9. Hasil Uji Autokorelasi

\begin{tabular}{ccc}
\hline & Model & Durbin Watson \\
\cline { 2 - 3 } & 1 & 1,773 \\
\hline
\end{tabular}

Uji autokorelasi ini dilakukan dengan menggunakan metode Durbin Watson Test. Variasi data tidak mengandung autokorelasi apabila statistik Durbin-Watson berkisar antara nilai 2, dengan nilai range antara -2 dan +2 . Berdasarkan tabel di atas, nilai durbin-watson sebesar 1,773. Artinya tidak mengandung autokorelasi.

Analisis Regresi Linier Berganda

Tabel 10. Hasil Regresi Linier Berganda

\begin{tabular}{|c|c|c|c|c|c|c|}
\hline & & \multicolumn{2}{|c|}{$\begin{array}{l}\text { Coefficients }^{\mathrm{a}} \\
\text { Unstandardized } \\
\text { Coefficients }\end{array}$} & \multirow{2}{*}{$\begin{array}{l}\text { Standardized } \\
\text { Coefficients } \\
\quad \text { Beta }\end{array}$} & \multirow[b]{2}{*}{$\mathbf{t}$} & \multirow[b]{2}{*}{ Sig. } \\
\hline \multicolumn{2}{|c|}{ Model } & B & $\begin{array}{c}\text { Std. } \\
\text { Error }\end{array}$ & & & \\
\hline & (Constant) & 1,599 & ,291 & & 5,492 & ,000 \\
\hline & Produk & ,305 & ,101 & ,303 & 3,019 & ,003 \\
\hline & Harga &,- 015 &, 096 &,- 016 &,- 158 &, 874 \\
\hline
\end{tabular}




\begin{tabular}{lrrrrr}
\hline Tempat &,- 016 &, 055 &,- 019 &,- 290 &, 772 \\
Promosi &, 375 &, 058 &, 431 & 6,513 &, 000
\end{tabular}

Dependent Variable: Keputusan Pembelian

\section{Sumber: Diolah (2020)}

Berdasarkan tabel didapatkan persamaan regresi sebagai berikut:

$$
\mathrm{KP}=0,305 \mathrm{P}+(-0,015) \mathrm{H}+(-0,016) \mathrm{T}+0,375 \mathrm{Pr}
$$

Nilai koefisien regresi produk $(\mathrm{P})$ sebesar 0,305 menunjukkan adanya pengaruh searah yang positif produk (P) pada keputusan pembelian (KP). Artinya apabila produk (P) naik sebesar satu satuan, maka keputusan pembelian (KP) akan naik sebesar 0,305 dengan asumsi besarnya harga (H), tempat (T), dan promosi (Pr) adalah tetap. Nilai koefisien regresi harga $(\mathrm{H})$ sebesar -0,015 menunjukkan adanya pengaruh berlawanan antara harga $(\mathrm{H})$ pada keputusan pembelian $(\mathrm{KP})$. Artinya apabila harga $(\mathrm{H})$ naik sebesar satu satuan, maka keputusan pembelian (KP) akan turun sebesar -0,015 dengan asumsi besarnya produk $(\mathrm{P})$, tempat $(\mathrm{T})$, dan promosi (Pr) adalah mengalami perubahan. Nilai koefisien regresi tempat (T) sebesar -0,016 menunjukkan adanya pengaruh berlawanan antara tempat (T) pada keputusan pembelian (KP). Artinya apabila tempat (T) naik sebesar satu satuan, maka keputusan pembelian (KP) akan turun sebesar -0,016 dengan asumsi besarnya produk $(\mathrm{P})$, harga $(\mathrm{H})$, dan promosi (Pr) adalah mengalami perubahan. Nilai koefisien regresi promosi (Pr) sebesar 0,375 menunjukkan adanya pengaruh searah yang positif promosi (Pr) pada keputusan pembelian (KP). Artinya apabila promosi (P) naik sebesar satu satuan, maka keputusan pembelian (KP) akan naik sebesar 0,375 dengan asumsi besarnya produk $(\mathrm{P})$, tempat $(\mathrm{T})$, dan promosi $(\mathrm{Pr})$ adalah tetap.

\section{Koefisien Determinasi $\left(R^{2}\right)$}

\section{Tabel 11. Hasil Koefisien Determinasi $\left(\mathbf{R}^{2}\right)$}

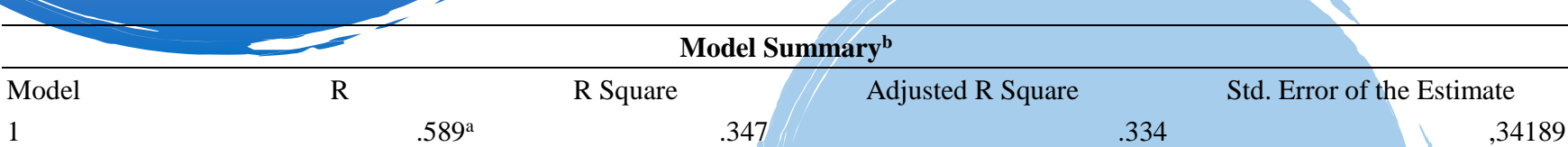

a. Predictors: (Constant), Promosi, Produk, Tempat, Harga

b. Dependent Variable: Keputusan Pembelian

Sumber: Diolah (2020)

Berdasarkan Tabel di atas dapat diketahui besarnya $\mathrm{R}^{2}$ adalah sebesar 0,347 yang berarti bahwa 34,7 \% variabel keputusan pembelian (KP) dapat dijelaskan oleh variabel produk $(\mathrm{P})$, harga $(\mathrm{H})$, tempat $(\mathrm{T})$, dan promosi (Pr) sedangkan sisanya sebesar 65,3\% dijelaskan oleh variabel-variabel lain di luar model yang diteliti dalam penelitian ini. Di samping itu nilai $\mathrm{R}^{2}$ sebesar 0,347 terarah mendekati angka 1 yang menggambarkan bahwa model persamaan yang dibangun sudah cukup baik.

\section{Uji Hipotesis Simultan $(F)$}

Tabel 12. Hasil Uji F

\begin{tabular}{|c|c|c|c|c|c|c|}
\hline \multicolumn{7}{|c|}{ ANOVA $^{b}$} \\
\hline & & Sum of Squares & $\mathrm{df}$ & Mean Square & $\mathrm{F}$ & \\
\hline \multirow[t]{3}{*}{1} & Regression & 12,435 & 4 & 3,109 & 26,595 & $.000^{b}$ \\
\hline & Residual & 23,378 & 200 &, 117 & & \\
\hline & Total & 35,812 & 204 & & & \\
\hline \multicolumn{7}{|c|}{ a. Dependent Variable: Keputusan Pembelian } \\
\hline \multicolumn{7}{|c|}{ b. Predictors: (Constant), Promosi, Produk,Tempat, Harga } \\
\hline
\end{tabular}


Berdasarkan uji Anova diperoleh nilai $\mathrm{F}$ hitung sebesar 26,595 dengan nilai signifikansi sebesar 0,000 lebih kecil dari 0,05, dengan demikian dapat disimpulkan bahwa kesesuaian variabel dapat dijelaskan oleh variabel Keputusan Pembelian (KP) dapat dijelaskan oleh variabel produk $(\mathrm{P})$, harga $(\mathrm{H})$, tempat $(\mathrm{T})$, dan promosi (Pr) berpengaruh secara bersama-sama terhadap keputusan pembelian (KP). Beradasarkan tabel di atas, maka nilai signifikansi menurut hasil perhitungan lebih kecil daripada nilai level of significance, maka $\mathrm{H} 0$ ditolak dan H5 diterima.

Uji Hipotesis Parsial ( $t$ )

Tabel. 13 Hasil Uji t

\begin{tabular}{|c|c|c|c|c|c|c|}
\hline & & \multicolumn{2}{|c|}{$\begin{array}{l}\text { Coefficients }^{\mathbf{a}} \\
\text { Unstandardized } \\
\text { Coefficients }\end{array}$} & \multirow{2}{*}{$\begin{array}{c}\text { Standardized } \\
\text { Coefficients } \\
\text { Beta }\end{array}$} & \multirow[b]{2}{*}{$\mathbf{t}$} & \multirow[b]{2}{*}{ Sig. } \\
\hline \multicolumn{2}{|c|}{ Model } & B & $\begin{array}{c}\text { Std. } \\
\text { Error }\end{array}$ & & & \\
\hline 1 & (Constant) & 1,599 & ,291 & & 5,492 & , 000 \\
\hline & Produk & ,305 & ,101 & ,303 & 3,019 & ,003 \\
\hline & Harga &,- 015 & ,096 &,- 016 &,- 158 & ,874 \\
\hline & Tempat &,- 016 & ,055 &,- 019 &,- 290 & ,772 \\
\hline & Promosi &, 375 & ,058 &, 431 & 6,513 & ,000 \\
\hline 0 & Dependent & elian & & & & \\
\hline
\end{tabular}

Untuk mengetahui nilai t tabel, maka menggunakan t tabel dengan tingkat signifikan a dengan nilai 5\%, dengan menggunakan uji dua arah dan derajat kebebasan yaitu n-k $(205-5=200)$. Maka diperoleh t tabel sebesar 1,65251. Berdasarkan data pada tabel di atas, nilai t hitung sebesar 3,019. Karena nilai t hitung < t tabel $(3,019<$ 1,65251) dan nilai probabilitas signifikansi $(0,005<0,05)$ maka $\mathrm{H} 0$ ditolak dan $\mathrm{H} 1$ diterima. Artinya produk secara parsial berpengaruh positif signifikan terhadap keputusan pembelian pada pengguna iPhone 6 Series di Universitas Nasional Jakarta. Untuk mengetahui nilai t tabel, maka menggunakan t tabel dengan tingkat signifikan a dengan nilai 5\%, dengan menggunakan uji dua arah dan derajat kebebasan yaitu n-k $(205-5=200)$. Maka diperoleh $\mathrm{t}$ tabel sebesar 1,65251. Berdasarkan data pada tabel di atas, nilai t hitung sebesar $-0,158$. Karena nilai $t$ hitung $>\mathrm{t}$ tabel $(-0,290>1,65251)$ dan nilai probabilitas signifikansi $(0,005<0,05)$ maka H0 ditolak dan $\mathrm{H} 2$ diterima. Artinya harga secara parsial tidak berpengaruh positif signifikan terhadap keputusan pembelian pada pengguna iPhone 6 Series di Universitas Nasional Jakarta.

Untuk mengetahui nilai $\mathrm{t}$ tabel, maka menggunakan $\mathrm{t}$ tabel dengan tingkat signifikan a dengan nilai 5\%, dengan menggunakan uji dua arah dan derajat kebebasan yaitu n-k $(205-5=200)$. Maka diperoleh $\mathrm{t}$ tabel sebesar 1,65251. Berdasarkan data pada tabel di atas, nilai t hitung sebesar $-0,290$. Karena nilai $t$ hitung $>t$ tabel $(-0,290$ $>1,65251)$ dan nilai probabilitas signifikansi $(0,005<0,05)$ maka H0 ditolak dan $\mathrm{H} 3$ diterima. Artinya tempat secara parsial tidak berpengaruh positif signifikan terhadap keputusan pembelian pada pengguna iPhone 6 Series di Universitas Nasional Jakarta. Untuk mengetahui nilai t tabel, maka menggunakan t tabel dengan tingkat signifikan a dengan nilai 5\%, dengan menggunakan uji dua arah dan derajat kebebasan yaitu n-k $(205-5=200)$. Maka diperoleh $t$ tabel sebesar 1,65251. Berdasarkan data pada tabel di atas, nilai t hitung sebesar 6,513. Karena nilai $\mathrm{t}$ hitung < t tabel $(6,513<1,65251)$ dan nilai probabilitas signifikansi $(0,005<0,05)$ maka H0 ditolak dan H4 diterima. Artinya promosi secara parsial berpengaruh positif signifikan terhadap keputusan pembelian pada pengguna iPhone 6 Series di Universitas Nasional Jakarta. 


\section{Pembahasan}

Berdasarkan hasil pengujian hipotesis menunjukkan bahwa produk memiliki nilai t-statistik 3,019 dengan tingkat signifikansi sebesar 0,003 yang kurang dari 0,05. Sehingga dapat disimpulkan bahwa variabel produk $(\mathrm{P})$ berpengaruh positif dan signifikan terhadap keputusan pembelian (KP). Nilai koefisien regresi produk $(\mathrm{P})$ sebesar 0,305 menunjukkan apabila produk $(\mathrm{P})$ naik sebesar satu satuan, maka keputusan pembelian (KP) akan naik sebesar 0. Hasil penelitian ini sesuai dengan penelitian yang dilakukan oleh Parmana, Fahmi, dan Nurrohmat (2019) menunjukkan bahwa produk berpengaruh positif dan signifikan terhadap keputusan pembelian. Secara konseptual produk adalah pemahaman subyektif dari produsen atas sesuatu yang bisa ditawarkan sebagai usaha untuk mencapai tujuan organisasi melalui pemenuhan kebutuhan dan keinginan konsumen, sesuai dengan kompetensi dan kapasitas organisasi serta daya beli (Supriyono, Hasiolan, \& Warso, 2014). Sebuah keputusan pembelian adalah tahap evaluasi, di mana preferensi konsumen terhadap sebuah merek terbentuk. Konsumen juga membentuk tujuan membeli merek yang paling disukai selama tahap ini (Albari \& Safitri, 2018).

Faktor produk sendiri merupakan hal yang diperhatikan konsumen dalam mengambil keputusan. Produk yang dijual harus mempunyai kualitas yang baik, unik dan penampilan yang menarik sehingga dapat membuat konsumen tertarik untuk membeli. Kualitas produk yang baik akan mendorong perusahaan untuk mempertahankan usahanya dan mampu bersaing dengan pesaing lainnya. Produk adalah segala sesuatu yang dapat ditawarkan ke pasar untuk diamati, disukai, dan dibeli untuk memuaskan sesuatu kebutuhan atau keinginan. Oleh karena produk dapat memenuhi kebutuhan tertentu maka produk dapat juga diartikan sebagai sekelompok nilai yang mampu membuat keputusan untuk melakukan pembelian. Keputusan pembelian konsumen adalah membeli merek yang paling disukai dari berbagai alternatif yang ada, tetapi dua faktor bisa berada antara niat pembelian dan keputusan pembelian. Faktor pertama adalah sikap orang lain dan faktor yang kedua adalah faktor situasional. Oleh karena itu, preferensi dan niat pembelian tidak selalu menghasilkan pembelian yang aktual. Keputusan pembelian merupakan kegiatan pemecahan masalah yang dilakukan individu dalam pemilihan alternatif perilaku yang sesuai dari dua alternatif perilaku atau lebih dan dianggap sebagai tindakan yang paling tepat dalam membeli dengan terlebih dahulu melalui tahapan proses pengambilan keputusan.

Berdasarkan hasil pengujian hipotesis menunjukkan bahwa harga memiliki nilai t-statistik -0,158 dengan tingkat signifikansi sebesar 0,874 yang lebih dari 0,05. Sehingga dapat disimpulkan bahwa variabel harga $(\mathrm{H})$ tidak berpengaruh positif dan signifikan terhadap keputusan pembelian (KP). Nilai koefisien regresi harga (H) sebesar -0,015 menunjukkan apabila harga $(\mathrm{H})$ naik sebesar satu satuan, maka keputusan pembelian (KP) akan turun sebesar 0. Hasil penelitian ini sesuai dengan penelitian yang dilakukan oleh Mawahib (2015) bahwa harga tidak berpengaruh positif dan signifikan terhadap keputusan pembelian. Hal tersebut berarti bahwa harga masih dapat dipertimbangkan oleh konsumen dalam pembelian, sehingga tidak mempengaruhi keputusan pembelian. Harga merupakan salah satu faktor penentu keberhasilan suatu perusahaan karena harga menentukan berapa banyak keuntungan perusahaan akan mendapatkan dari menjual produknya dari bentuk barang atau jasa. Menetapkan harga terlalu tinggi akan menyebabkan penjualan menurun, namun jika harga terlalu rendah akan mengurangi keuntungan yang dapat diperoleh dengan organisasi perusahaan (Subaebasni, Risnawaty, \& Wiaksono, 2019). Perusahaan harus menetapkan harga jual untuk yang pertama kalinya, terutama pada saat mengembangkan produk baru. Penetapan harga jual berpotensi menjadi suatu masalah karena keputusan penetapan harga jual cukup kompleks dan harus memperhatikan berbagai aspek yang mempengaruhinya (Kodu, 2013).

Dari sudut pandang pemasaran, harga merupakan satuan moneter atau ukuran lainnya yang ditukarkan agar memperoleh hak kepemilikan atas penggunaan suatu barang dan jasa. Sudut pandang konsumen mengatakan harga sering kali digunakan sebagai indikator nilai bilamana harga tersebut dihubungkan dengan manfaat yang dirasakan atas suatu barang atau jasa. Nilai dapat didefinisikan sebagai rasio antara manfaat yang dirasakan dengan harga. Pada tingkat harga tertentu bila manfaat yang dirasakan meningkat, maka nilainya meningkat pula. Keputusan pembelian adalah tahap proses keputusan di mana konsumen membeli produk. 


\section{orew Q Access}

Konsumen sebagai aktor utama dalam proses pembelian selalu menjadi perhatian produser. keputusan pembelian yang dilakukan oleh konsumen dapat terjadi jika pelanggan telah menerima layanan dari penyediaan layanan dan setelah itu konsumen merasakan kepuasan dan ketidakpuasan (Lahindah, Merisa, \& Siahaan, 2018).

Berdasarkan hasil pengujian hipotesis menunjukkan bahwa tempat memiliki nilai t-statistik -0,290 dengan tingkat signifikansi sebesar 0,772 yang lebih dari 0,05. Sehingga dapat disimpulkan bahwa variabel tempat $(\mathrm{T})$ tidak berpengaruh positif dan signifikan terhadap keputusan pembelian (KP). Nilai koefisien regresi tempat (T) sebesar -0,016 menunjukkan apabila tempat (T) naik sebesar satu satuan, maka keputusan pembelian (KP) akan turun sebesar 0. Hasil penelitian ini sesuai dengan penelitian yang dilakukan oleh Mawahib (2015) bahwa tempat tidak berpengaruh positif dan signifikan terhadap keputusan pembelian. Hal tersebut berarti bahwa tempat perusahaan atau toko di mana saja tidak mempengaruhi keputusan konsumen dalam melakukan pembelian terhadap suatu produk. Lokasi atau tempat sering menentukan keberhasilan perusahaan, karena lokasi itu terkait era dengan pasar potensial perusahaan. Selain itu, lokasi juga mempengaruhi dimensi strategi seperti fleksibilitas, persaingan, penentuan posisi, dan fokus. Fleksibilitas lokasi adalah ukuran sejauh mana perusahaan dapat bereaksi terhadap perubahan dalam situasi ekonomi. Keputusan pemilihan lokasi berkaitan dengan komitmen jangka panjang untuk aspek-aspek yang padat modal, maka perusahaan benar-benar perlu mempertimbangkan dan memilih lokasi yang responsif terhadap situasi ekonomi, demografi, budaya dan persaingan di masa depan (Selang, 2013).

Keputusan pembelian konsumen adalah tindakan individu yang secara langsung atau tidak langsung terlibat dalam bisnis memperoleh dan menggunakan produk atau layanan yang diperlukan (Rommy \& Nur, 2018). Keputusan pembelian konsumen adalah perilaku yang ditunjukkan oleh pengambilan keputusan unit dalam pembelian, penggunaan dan pembuangan barang dan jasa. keputusan pembelian konsumen adalah proses pengambilan keputusan dan aktivitas fisik individu terlibat dalam ketika mengevaluasi, memperoleh, menggunakan atau membuang barang dan jasa (Khuong \& Duyen, 2016). Kurangnya informasi mengenai lokasi outlet resmi serta service center iPhone oleh konsumen, sehingga terkadang kesulitan mendapatkan produk yang diinginkan. Dengan demikian perusahaan agar dapat lebih meningkatkan dan memperhatikan lokasi outlet resmi, sehingga perusahaan dapat lebih mudah menyebarkan produknya dan konsumen juga dapat lebih mudah untuk memperoleh produk yang diinginkan.

Berdasarkan hasil pengujian hipotesis menunjukkan bahwa promosi memiliki nilai t-statistik 6,513 dengan tingkat signifikansi sebesar 0,000 yang kurang dari 0,05. Sehingga dapat disimpulkan bahwa variabel promosi (Pr) berpengaruh positif dan signifikan terhadap keputusan pembelian (KP). Nilai koefisien regresi promosi (Pr) sebesar 0,375 menunjukkan apabila promosi (Pr) naik sebesar satu satuan, maka keputusan pembelian (KP) akan naik sebesar 0. Hasil penelitian ini sesuai dengan penelitian yang dilakukan oleh Nurrohmat (2019) menunjukkan bahwa promosi berpengaruh positif dan signifikan terhadap keputusan pembelian. Hal ini berarti bahwa semakin tepat pemilihan promosi yang dilakukan perusahaan maka semakin tertarik pula konsumen untuk membeli sehingga akan menimbulkan keputusan konsumen untuk membeli suatu produk.

Promosi adalah upaya untuk memberitahukan atau menawarkan produk atau jasa dengan tujuan menarik calon konsumen untuk membeli atau dikenakan dengan promosi produsen atau distributor mengharapkan peningkatan jumlah penjualan, di mana promosi adalah salah satu kegiatan pemasaran yang penting untuk perusahaan dalam upaya untuk menjaga kesinambungan dan meningkatkan kualitas penjualan (Rasmansyah, 2017). Keputusan pembelian adalah proses kognitif memilih tindakan dari antara beberapa alternatif. Contoh umum termasuk belanja dan memutuskan apa yang harus makan. Pengambilan keputusan dikatakan konstruk psikologis. Ini berarti bahwa meskipun konsumen tidak pernah bisa 'melihat' keputusan, konsumen dapat menyimpulkan dari perilaku yang dapat diamati bahwa keputusan telah dibuat (Altekar \& Keskar, 2014). 


\section{PENUTUP}

Berdasarkan hasil penelitian yang dilakukan oleh peneliti, dapat ditarik kesimpulan bahwa Produk berpengaruh positif dan signifikan terhadap keputusan pembelian smartphone iPhone 6 series pada mahasiswa Universitas Nasional Jakarta. Hal ini berarti bahwa semakin tepat produk yang dijual maka semakin tertarik pula konsumen untuk membeli sehingga akan menimbulkan keputusan konsumen. Harga tidak berpengaruh terhadap keputusan pembelian smartphone iPhone 6 series pada mahasiswa Universitas Nasional Jakarta. Hal tersebut berarti bahwa harga masih dapat dipertimbangkan oleh konsumen dalam pembelian, sehingga tidak mempengaruhi keputusan pembelian. Tempat tidak berpengaruh terhadap keputusan pembelian smartphone iPhone 6 series pada mahasiswa Universitas Nasional Jakarta. Hal tersebut berarti bahwa tempat perusahaan atau toko di mana saja tidak mempengaruhi keputusan konsumen dalam melakukan pembelian terhadap suatu produk. Promosi berpengaruh positif dan signifikan terhadap keputusan pembelian smartphone iPhone 6 series pada mahasiswa Universitas Nasional Jakarta. Hal ini berarti bahwa semakin tepat pemilihan promosi yang dilakukan perusahaan maka semakin tertarik pula konsumen untuk membeli sehingga akan menimbulkan keputusan konsumen untuk membeli suatu produk.

Berdasarkan hasil penelitian yang dilakukan oleh peneliti, maka dapat diberikan beberapa saran di antaranya agar pihak iPhone dapat memberikan harga kepada konsumen dengan strata sosial menengah ke bawah sehingga dapat meningkatkan keputusan pembelian penggunanya. Selain itu dapat pula memberikan banyak tempat service iPhone sehingga menjadikan pembeli tidak bingung jika terjadi kerusakan pada iPhone yang dibelinya. Dan agar peneliti selanjutnya menambahkan variabel baru atau bisa juga menggunakan teknik analisa yang berbeda seperti path analysis dan juga Structural Equal Modelling dengan aplikasi SmartPLS.

\section{DAFTAR PUSTAKA}

Albari, \& Safitri, I. (2018). The Influence of Product Price on Consumers' Purchasing Decisions. Review of Integrative Business and Economics Research, 328-337.

Altekar, S., \& Keskar, A. (2014). A Study of the Factors Impacting the Buying Decision Process vis-à-vis Specified Consumer Durables in NOIDA. Journal of General Management Research, 111-123.

Foster, B. (2016). The Effect of Price and Service Quality on Customer Satisfaction in Mutiara Hotel Bandung. American Research Journal of Humanities and Social Sciences, 1-12.

Hermawan, H. (2015). Analisis Pengaruh Bauran Pemasaran terhadap Keputusan, Kepuasan, dan Loyalitas Konsumen dalam Pembelian Roti Ceria di Jember. Jurnal Manajemen dan Bisnis Indonesia Vol. 1 No. 2 , 143-161.

Khuong, M., \& Duyen, H. (2016). Personal Factors Affecting Consumer Purchase Decision towards Men Skin Care Products - A Study in Ho Chi Minh City, Vietnam. International Journal of Trade, Economics and Finance, 44-50.

Kodu, S. (2013). Harga, Kualitas Produk dan Kualitas Pelayanan Pengaruhnya terhadap Keputusan Pembelian Mobil Toyota Avanza. Jurnal EMBA, 1251-1259.

Lahindah, L., Merisa, \& Siahaan, R. (2018). The Influence of Product Innovation and Service Quality to Buying Decision and the Impact to Repeat Buying at Progo Road Bandung . The Asian Journal of Technology Management, 118-124.

Laksana, L., C. (2019). Penjualan iPhone Menurun Tahun Ini. Diakses dari https://www.tek.id/tek/penjualaniphone-menurun-tahun-ini-b1XpF9fVB pada Tanggal 13 April 2020 Pukul 16.01 WIB.

Makarewicz, A. (2013). Consumer Behavior as A Fundamental Requirement for Effective Operations of Companies. Journal of International Studies Vol. 6, No. 1, 103-109. 


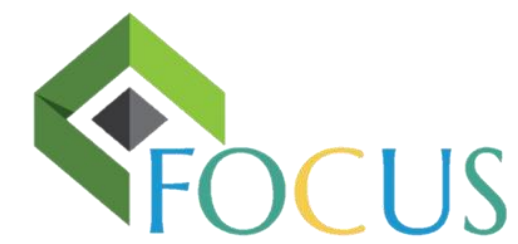

open_Access

Mawahib, M. (2015). Pengaruh Bauran Pemasaran terhadap Keputusan Pembelian Smartphone Samsung (Studi Kasus pada Mahasiswa Administrasi Bisnis Universitas Mulawarman). e-Journal Administrasi Bisnis, 858-872.

Odunlami, I., \& Emmanuel, A. (2014). Effect of Promotion on Product Awareness (A Case Study of A Reputable Organization in the Brewery Sub-Sector of the Manufacturing Industry). International Journal of Education and Research, 451-472.

Parmana, Fahmi, I., \& Nurrohmat, D. (2019). The Influence of Marketing Mix Factors in Purchasing Decision for Wooden Furniture Case of Furnimart Bogor. Indonesian Journal of Business and Entrepreneurship, 54-64.

Sefudin, A., \& Darwin, M. (2020). Perbandingan Teori Disrupsi pada Marketing di Era Industri 4.0 Menurut Hermawan Kartajaya dan Rhenald Kasali. In KOMITMEN: Jurnal Ilmiah Manajemen (Vol. 1, Issue 2).

Selang, C. (2013). Bauran Pemasaran (Marketing Mix) Pengaruhnya terhadap Loyalitas Konsumen pada Fresh

Mart Bahu Mall Manado. Jurnal EMBA, 71-80.

Subaebasni, S., Risnawaty, H., \& Wiaksono, A. (2019). Effect of Brand Image, the Quality and Price on Customer Satisfaction and Implications for Customer Loyalty PT Strait Liner Express in Jakarta. International Review of Management and Marketing, 90-97.

Ulus, A. (2013). Bauran Pemasaran Pengaruhnya terhadap Keputusan Pembelian Mobil Daihatsu pada PT. Astra Internaional Manado. Jurnal EMBA, 1134-1144.

Zakiah, N. (2020). Pasar Indonesia Dikuasai oleh 7 Brand HP Ini, Apa Sajakah?. Diakses dari https://www.idntimes.com/tech/gadget/nena-zakiah-1/brand-smartphone-yang-menguasai-marketindonesia/full pada Tanggal 13 April 2020 pukul 17.12 WIB.

Zulaicha, S., \& Irawati, R. (2016). Pengaruh Produk dan Harga terhadap Keputusan Pembelian Konsumen di Morning Bakery Batam. Jurnal Inovasi dan Bisnis, 125-136. 